\title{
CONTROLE DE CONSTITUCIONALIDADE PELO PO- DER EXECUTIVO E O ADICIONAL DE INSALUBRIDA- DE A FUNCIONÁRIOS E SERVIDORES PÚBLICOS
}

\author{
Judicial review by the executive branch and payment of additional \\ salary for working in unhealthy conditions to civil servants
}

\section{Mateus de Farias Klein}

Especialista em Direito do Estado pela UFRGS. Assessor do Gabinete da Procuradoria-Geral do Município de Porto Alegre. Foi subprocurador-geral do Município de Novo Hamburgo. Atua nas áreas: direito constitucional, administrativo e processo legislativo.E-mail: mateusklein@hotmail.com.

\section{Cristiane Catarina Fagundes de Oliveira}

Pós doutora pela UFRGS. Doutora em direito do Estado pela USP. Mestre em Direito do Estado pela UFRGS. Procuradora Municipal de Porto Alegre desde 1996. Professora universitária. E-mail: oliveira.cristianecatarina@gmail.com.

\section{Resumo}

O controle de constitucionalidade é exercido pelo Poder Judiciário, mas o Poder Executivo pode também exercer o controle de constitucionalidade fundado em interpretação da aplicação do princípio da legalidade e devido ao princípio da separação de poderes com sistema de freios e contrapesos. De outro lado, a discussão sobre o estabelecimento da base de cálculo do adicional de insalubridade no salário mínimo foi decidida no sentido da inconstitucionalidade. O objetivo do trabalho é questionar se, em casos como esse do adicional de insalubridade, é possível que o Poder Executivo declare inconstitucional dispositivo de seu estatuto e determine nova base de cálculo. O método utilizado é da revisão bibliográfica e estudo de jurisprudência específica.

Palavras-chave: Controle de constitucionalidade. Poder Executivo. Princípio da Legalidade. Adicional de Insalubridade.

\begin{abstract}
Judicial Review is exercised by the judiciary, but the executive branch may also exercise Judicial Review based on interpretation of the application of the principle of due process and due to the separation of powers doctrine and with checks and balances system. On the other hand, the discussion about the establishment of the basis for calculating the payment of additional salary for working in unhealthy conditions was decided in the sense of unconstitutionality. The objective of this paper is to question whether, in cases such as this, the payment of additional salary for working in unhealthy conditions, it is possible that the Executive Branch declares a statute unconstitutional and determines a new basis for calculation. The method used is the literature review and study of specific law cases.
\end{abstract}

Keywords: Judicial Review. Executive branch. Due Process of law. Payment. Unhealthy Conditions.

\section{Sumário}

1. Introdução; 2. Controle de constitucionalidade e princípio da legalidade; 2.1 Do princípio da legalidade; 2.2 Do Controle de Constitucionalidade; 2.3 Do exercício do controle de constitucionalidade pelo Poder Executivo; 3 Adicional de insalubridade e norma inconstitucional; 4 Conclusão; 5. Notas; Referências 


\section{INTRODUÇÃO}

O controle de constitucionalidade está inserido na ideia da separação de poderes, com o sistema de freios e contrapesos, e é função dos poderes de Estado.

Em que pese o controle de constitucionalidade seja realizado, ordinariamente, pelo Poder Judiciário, não cabe a ele apenas exercer o referido controle. A Constituição de 1988 confere como regra geral a competência ao Poder Judiciário para o exercício do controle de constitucionalidade, porém não veda que outros Poderes possam fazê-lo.

O Poder Executivo, como os demais, está atrelado ao princípio da legalidade, ou seja, está adstrito ao cumprimento do que a lei determina. Porém, nem sempre a lei está de acordo com a Constituição, violando dispositivos constitucionais. A controvérsia se estabelece quanto à legitimidade do Poder Executivo em afastar a aplicação de norma legal sem o prévio reconhecimento judicial da inconstitucionalidade, em vista do princípio da legalidade. Busca-se analisar o controle de constitucionalidade por parte do Poder Executivo, seja pelo método preventivo ou repressivo.

Por fim, examina-se a questão do adicional de insalubridade, devido a empregados regidos pela Consolidação das Leis do Trabalho (CLT) e a servidores públicos, nos termos estatutários. Questiona-se a possibilidade de o Poder Executivo deixar de aplicar norma relativa à base de cálculo do adicional de insalubridade, com fundamento na inconstitucionalidade de norma que determina a utilização do salário mínimo como indexador. Também se analisa a possibilidade de o Executivo fixar outra base de cálculo até que nova lei a defina.

\section{CONTROLE DE CONSTITUCIONALIDADE E PRINCÍPIO DA LEGALIDADE}

O controle de constitucionalidade realizado pelo Poder Judiciário é feito de forma repressiva. Ao Poder Executivo pode ser concedida a legitimidade de negar cumprimento a norma legal, diante de sua inconstitucionalidade, eis que a mesma apresenta vício, formal ou material, observando a supremacia das normas constitucionais, em detrimento ao princípio da legalidade estrita.

\subsection{DO PRINCÍPIO DA LEGALIDADE}

O princípio da legalidade é aquele pelo qual a Administração Pública só pode fazer o que a lei determinar ou permitir. Está previsto expressamente no caput do art. 37 da Constituição Federal ${ }^{1}$, in verbis:

Art. 37. A administração pública direta e indireta de qualquer dos Poderes da União, dos Estados, do Distrito Federal e dos Municípios obedecerá aos princípios de legalidade, impessoalidade, moralidade, publicidade e eficiência e, também, ao seguinte [...]

A Constituição de 1988 implica que todos os entes devem observar ao princípio da legalidade, o qual abrange tanto a lei formal, votada pelo Poder Legislativo, quanto aos preceitos que norteiam o Estado de Direito. Assim, cabe a Administração sujeitar-se as normas legais. $^{2}$

A Administração deve apenas cumprir o que a lei determina ou preceder naquilo que 
ela autoriza, cabendo a ela se cumpridora das disposições gerais fixadas pelo Poder Legislativo, devendo o Poder Executivo em não olvidar esforços para o cumprimento do comando legal. ${ }^{3}$

Logo, segundo o princípio da legalidade, o Poder Executivo, segundo preconiza a Constituição, deve cumprir e fazer cumprir o que ela determina.

\title{
2.2 DO CONTROLE DE CONSTITUCIONALIDADE
}

O controle de constitucionalidade é o mecanismo de verificação da compatibilidade de um ato normativo em face da Constituição. As normas que compõem o ordenamento jurídico brasileiro devem estar de acordo com a Constituição de 1988, ou seja, devem guardar uma compatibilização vertical. O controle de constitucionalidade tem por fundamento o princípio da Supremacia Constitucional, o qual dispõe de que as normas constitucionais estão no ápice da pirâmide hierárquica de Kelsen. ${ }^{4}$

Michel Temer, ${ }^{5}$ em análise dos pressupostos do controle de constitucionalidade, indica:

\begin{abstract}
O Controle de Constitucionalidade pressupõe, necessariamente o reconhecimento da supremacia da Constituição, ou seja, a existência de um escalonamento normativo, onde o texto constitucional ocupa o ponto mais alto do sistema normativo e também a existência de uma Constituição rígida, onde o poder constituinte originário estabelece um processo mais árduo de modificação constitucional (ou nenhum processo modificativo) que o processo de elaboração normativa inferior. (TEMER, 2006, p. 44-45).
\end{abstract}

O princípio da Supremacia Constitucional é fundamental para o controle de constitucionalidade. José Afonso da Silva ${ }^{6}$ explica tal princípio da seguinte forma:

\begin{abstract}
O princípio da supremacia da constituição que, no dizer de Pinto Ferreira, 'é reputado como pedra angular, em que assenta o edifício do moderno direito político'. Significa que a constituição se coloca no vértice do sistema jurídico do país, a que confere validade, e que todos os poderes estatais são legítimos na medida em que ela os reconheça e na proporção por ela distribuídos. É, enfim, a lei suprema do Estado, pois é nela que se encontram a própria estruturação deste e a organização de seus órgãos; é nela que se acham as normas fundamentais de Estado, e só nisso se notará sua superioridade em relação às demais normas jurídicas.
\end{abstract}

Logo, a Constituição está o topo da pirâmide das normas, sendo que as leis e normas não podem contrariá-la, de modo material ou formal, sob pena de incorrer em inconstitucionalidade.

Clèmerson Merlim Clève ${ }^{7}$ ensina:

[...] a compreensão da Constituição como Lei Fundamental implica não apenas o reconhecimento de sua supremacia na ordem jurídica, mas, igualmente, a existência de mecanismos suficientes para garantir juridicamente (eis um ponto importante) apontada qualidade. A supremacia diga-se logo, não exige apenas a compatibilidade formal do direito infraconstitucional com os comandos maiores definidos do modo de produção das normas jurídicas, mas também a observância de sua dimensão material. A Constituição, afinal, como quer Hesse, é uma 'ordem fundamental, material e aberta de uma comunidade'. É uma ordem, eis que reside sua posição de supremacia. É ademais, ordem material porque além de normas, contém uma ordem de valores: o conteúdo do direito, que não pode ser desatendido pela regulação infraconstitucional.

Alexandre de Moraes, ${ }^{8}$ ao tratar sobre o controle de constitucionalidade, refere: "Con- 
trolar a constitucionalidade significa verificar a adequação (compatibilidade) de uma lei ou de um ato normativo com a Constituição, verificando seus requisitos formais e materiais."

Logo, é imprescindível falar em controle de constitucionalidade sem reconhecer o princípio da supremacia da Constituição.

O controle de constitucionalidade pode ser classificado quanto ao seu momento como preventivo ou repressivo. Pode ser exercido de forma prévia ou preventiva e posterior ou repressiva à edição do ato normativo.

O controle preventivo busca impedir que a norma viciada pela inconstitucionalidade ingresse no ordenamento jurídico, o projeto de lei, e não a lei, por exemplo, é objeto de questionamento, é ele que tem a sua constitucionalidade questionada. O controle repressivo, ou o controle superveniente, busca extirpar a norma eivada de vício inconstitucional, a lei editada, promulgada, já produz efeitos no mundo jurídico, sendo que normalmente que faz o controle repressivo é Poder Judiciário. ${ }^{9}$

\subsection{DO EXERCÍCIO DO CONTROLE DE CONSTITUCIONALIDADE PELO PODER EXECUTIVO}

O princípio da legalidade determinado pela Constituição implica o Poder Executivo com o dever de atuar em conformidade com as normas da Constituição, em conformidade com o Direito, e não somente observar o que a Lei em específico determina. O Poder Executivo não está obrigado a acatar normas legislativas contrárias à Constituição até que o Poder Judiciário decida a respeito. ${ }^{10}$

A doutrina é controversa a respeito da possibilidade ou não do exercício do controle de constitucionalidade por poder alheio ao Poder Judiciário. Elival da Silva Ramos, ${ }^{11}$ Hely Lopes Meirelles ${ }^{12}$ e Luís Roberto Barroso ${ }^{13}$ destacam que quando o ordenamento estabelece sanção de nulidade para as leis que violem as normas constitucionais, poderia o Poder Executivo em negar o cumprimento à lei inconstitucional.

Este posicionamento é combatido por outra parte doutrinária que defende que em razão dos instrumentos disponibilizados pela Constituição de 1988 é inadmissível que o Poder Executivo negue o cumprimento da lei. Caberia ao Chefe do Poder Executivo, ao se deparar com norma inconstitucional, provocar o Poder Judiciário para que decida sobre o reconhecimento ou não da invalidade da norma frente à Constituição. ${ }^{14} \mathrm{~A}$ Lei Federal n. 9.868/19991, confere ao Chefe do Poder Executivo da União o poder de manejar Ação Direta de Inconstitucionalidade para que o Poder Judiciário aprecie em sede de controle concentrado a constitucionalidade da norma. ${ }^{15}$

O Ministro Gonçalves de Oliveira, citado por Sara Meinberg Schmid, ${ }^{16}$ em decisão judicial proferida nos autos do Mandado de Segurança $n^{\circ} 15.886$, julgado pelo Supremo Tribunal Federal em 1966, analisou o tema da seguinte forma:

A lei é iniciada e votada pelo Congresso Nacional, depois sobe à sanção. Se o Presidente da República, o Governador do Estado ou Prefeito sanciona a lei, parece claro que nem ele nem qualquer funcionário administrativo poderá descumpri-la, sob o fundamento de que é inconstitucional. O momento preciso para repudiar a lei seria o da sanção. O Poder Executivo oporia o veto, então 
a lei voltaria ao Congresso, às Assembleias ou às Câmaras Municipais, e seria mantida ou não a proposição com o voto qualificado. Este é o nosso regime constitucional.

Portanto, em princípio, a regra é que, sancionando o Presidente da República a lei, ele supre quaisquer deficiências de trânsito, nas normas legislativas. Teve o momento que a Constituição Ihe consagrou para dizer se a proposição era constitucional ou inconstitucional. Se nesse momento não usou de seu poder, parece claro que dá-se o consenso pelo Executivo de que a norma seja constitucional. Se o Presidente, no entanto, veta a proposição, ela volta, no caso de lei federal, ao Congresso que, por maioria altamente qualificada de dois terços, manterá ou não o veto. Se mantiver, temos uma lei que o Presidente da República é obrigado a observar, nos termos da Constituição. Este é o princípio do nosso direito constitucional. Às vezes, como no caso de que se trata, há uma questão intercorrente. É que o Presidente veta a lei e o seu veto é rejeitado pelo Congresso Nacional. Surge a questão: o Poder Executivo, o Presidente da República pode opor-se ao cumprimento da lei? Entendo que a lei poderia ser levada ao conhecimento do Supremo Tribunal Federal, através da Procuradoria-Geral da República. Mas reconheço que essa não é a doutrina corrente.

A demora na retirada da norma inconstitucional do ordenamento pelo Poder Judiciário é uma das justificativas que a doutrina majoritária adota no sentido de possibilitar que o Poder Executivo negue vigência a lei inconstitucional. Desde a publicação da lei até a declaração da sua inconstitucionalidade a lei poderia gerar efeitos que poderiam ocasionar em prejuízos. Estabelece-se o conflito entre o princípio da legalidade com o da força normativa da Constituição. ${ }^{17}$

Konrad Hesse,$^{18}$ ao abordar o princípio da força normativa da Constituição, ensina:

Nenhum poder do mundo, nem mesmo a Constituição, pode alterar as condicionantes naturais. Tudo depende, portanto, e que se conforme a Constituição a esses limites. Se os pressupostos da força normativa encontrarem correspondência na Constituição, se as forças em condições de violá-la ou de alterá-la mostrarem-se dispostas a render-lhe homenagem, se, também em tempos difíceis, a Constituição lograr preservar a sua força normativa, então ela configura verdadeira força viva capaz de proteger a vida do Estado contra as desmedidas investidas do arbítrio. Não é, portanto, em tempos tranquilos e felizes que a Constituição normativa vê-se submetida à sua prova de força. Em verdade, esta prova dá-se nas situações de emergência, nos tempos de necessidade.

Esse princípio ampara ambas correntes doutrinárias, tanto a que defende a possibilidade de negativa de vigência por parte do Poder Executivo, quanto a que defende pela impossibilidade de negativa de vigência por parte do Poder Executivo. O Chefe do Executivo poderia, ao se deparar com uma lei inconstitucional, não aplicá-la ou afastar o seu cumprimento, sob o argumento de cumprimento da Constituição. Seguir este entendimento, em consonância com a corrente majoritária, seria primar pela regra Constitucional, fortalecendo-a. ${ }^{19}$

Diante disso, em situações excepcionais poderia o Poder Executivo estar legitimado a recusar o cumprimento da lei, como por exemplo, nos flagrantes casos de vício de iniciativa. $^{20}$

$$
\text { O juiz federal Flávio da Silva Andrade }{ }^{21} \text { entende, }
$$

Assim, dentro do quadro de excepcionalidade que deve nortear essa possibilidade, há de se exigir o preenchimento dos seguintes requisitos:

a) tratar-se de caso em que, exercendo o direito de interpretação no caso concreto, de maneira motivada, o Chefe do Executivo venha a deparar-se com situação de manifesta inconstitucionalidade, de modo que se torne evidente a 


\begin{abstract}
necessidade de repudiar a lei para prestigiar a supremacia da Carta Constitucional. Nessas hipóteses, o ocupante da Chefia do Poder Executivo não pode ter tido a oportunidade de vetar a lei reputada inconstitucional, pois, do contrário, seria incongruente recusar o cumprimento de norma que ele mesmo considerou constitucional;

b) como recorda Elival da Silva Ramos, citado por Alexandre de Moraes (2006, p. 639), por se tratar de medida extremamente grave e com ampla repercussão nas relações entre os Poderes, apenas ao Chefe do Poder Executivo pode ser assegurada essa prerrogativa, negando-se a possibilidade de qualquer funcionário administrativo subalterno descumprir a lei sob a alegação de inconstitucionalidade.
\end{abstract}

Entende o magistrado que o poder para refutar a aplicação de lei inconstitucional recairia sobre o Chefe do Poder Executivo, sendo vedado que servidores ou funcionários rechacem a aplicação norma flagrantemente inconstitucional.

A primeira Turma do Supremo Tribunal Federal enfrentou o tema nos autos do Mandado de Segurança n. 27.744/DF, consagrando o entendimento de que todos estão submetidos a Constituição, inclusive órgãos administrativos. Permitiu o STF o afastamento de norma inconstitucional no caso em concreto, vedando a realização de controle concentrado.

O voto do Ministro Marco Aurélio 22 foi no seguinte sentido:

O Conselho atuou em cima de caso concreto e deixou de aplicar a lei, por tê-la como inconstitucional, observando a Constituição.

Todos estamos submetidos à Carta da República, que é a Lei das leis, inclusive o Conselho Nacional do Ministério Público. Algo é atuar de forma abstrata, vindo a declarar a incompatibilidade de uma lei com o Texto Constitucional. Coisa diversa é enfrentar situação concreta e entender que prevalece não a lei, no caso, estadual, mas sim a Constituição.

Esse dever toda a administração tem. A administração não está compelida a observar lei que tenha como incompatível com a Lei Maior. [...]

A primeira vez que o Supremo enfrentou essa matéria - pelo menos que me lembre, não por ter estado quando do julgamento, mas por visita a precedente -, atuou como relator o ministro Victor Nunes Leal, envolvia situação concreta em que o Tribunal de Contas da União deixara de observar lei para implementar a eficácia, a concretude, da Constituição Federal. O Supremo concluiu que era possível, porque, senão, chegar-se-ia a seguinte situação: estar todo órgão da Administração Pública compelido a observar lei ordinária em detrimento da Constituição. [...]

Ministro, a única dúvida é a seguinte: defronta-se o Conselho com um caso concreto e, com o dilema: homenagear a lei ou a Constituição Federal. Atuando, não exerce o controle difuso propriamente dito, porque órgão administrativo. Julga o caso administrativo concreto, desta ou daquela forma, ante a impossibilidade de homenagear a Carta da República? O sistema não fecha.

Nos debates do julgado, o Ministro Marco Aurélio inaugura a discussão acerca da possibilidade de no caso concreto ser afastada a aplicação da lei em homenagem a Constituição. O debate enfrentado é justamente se Poder alheio ao Judiciário poderia afastar a aplicação da lei, colocando de lado o princípio da legalidade, sob o fundamento da inconstitucionalidade da norma.

Pelo que se denota do posicionamento do Supremo Tribunal Federal, pode o Poder Executivo afastar a aplicação de norma sob o fundamento da inconstitucionalidade. Contudo, tal posição do Executivo não pode caracterizar um fluxo sem freios ou contrapesos, ou seja, não é uma posição de forma ilimitada, tem que haver ponderações quando do exercício do afastamento da norma inconstitucional. Deve obedecer aos demais princípios constitucio- 
nais, como da motivação, por exemplo.

O Ministro Luís Roberto Barroso, ${ }^{23}$ em sede de voto-vista, proferiu o seguinte entendimento:

\begin{abstract}
Conforme me pronunciei na sessão do dia 06.05.2014, concordo com o Min. Marco Aurélio no sentido de que quem tem a incumbência de aplicar a norma a uma situação concreta não pode ser compelido a deixar de aplicar a Constituição e aplicar a norma que considera incompatível. Não se trata, aqui, de realizar controle abstrato de constitucionalidade, mas, sim, de deixar de aplicar uma norma ao caso concreto, em face da supremacia da Constituição (controle incidental).
\end{abstract}

Verifica-se que no voto-vista do Ministro Barroso há o alinhamento no entendimento de que aquele que compete a aplicação da norma não pode ser obrigado a fazê-lo em detrimento das regras constitucionais, pelo contrário, impende que seja observada a supremacia das regras constitucionais.

O Ministro Barroso analisa sob o prisma que não se está a tratar de controle de constitucionalidade abstrato, mas em afastar a aplicação da norma considerada inconstitucional, face à supremacia da Constituição.

Em análise derradeira dos debates proferidos, cumpre novamente destacar o posicionamento do Ministro Marco Aurélio:24

\begin{abstract}
Presidente, reitero o que tive a oportunidade de veicular a partir de outro caso, ou seja, a existência de precedente sobre a matéria, da lavra do ministro Victor Nunes Leal, quando se consignou que órgão administrativo, seja qual for, pode deixar de aplicar lei que tenha como conflitante com a lei das leis, que é a Constituição Federal, observando esta última.

Seria verdadeira incongruência assentar-se a inexistência dessa possibilidade. Tornar-se-ia prevalecente, muito embora no campo administrativo, a lei inconstitucional. O que não pode o órgão administrativo é propriamente exercer o controle difuso, muito menos o concentrado, de constitucionalidade. É algo diverso, como ressaltou o ministro Luís Roberto Barroso.
\end{abstract}

Consagra a primeira turma do Supremo Tribunal Federal a possibilidade de, além do Poder Executivo e do Poder Legislativo, órgãos administrativos a possibilidade de afastarem a aplicação de lei que esteja em desacordo com a Constituição.

Pode-se afirmar que é possível interpretar a aplicação do princípio da legalidade em consonância ao controle de constitucionalidade pelo Executivo. Não se está em não ferir a lei, mas simplesmente em afastar sua aplicação em prol da Constituição.

Todavia, esta posição adotada pela Suprema Corte não implica em permitir que o Poder Executivo afaste da aplicação qualquer norma, ou seja, deve o ato cumprir com os demais princípios constitucionais, como o da motivação, a fim de permitir o afastamento da norma sob o argumento da inconstitucionalidade.

Nos termos expostos, deve o Poder Executivo se sujeitar as demais normas constitucionais, pois a decisão do Supremo Tribunal Federal não outorga poder ilimitado para afastar de forma injustificada toda e qualquer norma.

\title{
3. ADICIONAL DE INSALUBRIDADE E NORMA INCONSTITUCIONAL
}

O adicional de insalubridade está previsto no art. $7^{\circ}$, XXIII da Constituição de 1988, 
regulada na CLT no art. 189 e seguintes, aplicando-se aos empregados da iniciativa privada e aos empregados públicos regidos pelo regime celetista. Em relação aos servidores públicos de regime estatutário, ainda não haja aplicação do art. $7^{\circ}$, XXIII por força de norma constitucional, os estatutos podem instituir o adicional de insalubridade e, em geral, o fazem.

O adicional significa uma "parcela contraprestativa suplementar"25 ou o pagamento de uma "compensação"26 por estar o funcionário ou servidor submetido a condições de trabalho contrárias a um ambiente saudável de trabalho, ${ }^{27}$ inclusive com pagamento retroativo à data inicial da exposição. ${ }^{28} \mathrm{O}$ fundamento é a exposição "a agentes ou condições que colocam em risco a sua integridade física" (do trabalhador). ${ }^{29}$

A opção no Brasil com o pagamento de adicional de insalubridade, em que pese o disposto no art. 191 da CLT, parece mascarar a obrigação patronal em elidir os riscos à saúde do empregado ou servidor. Nos Estados Unidos, não há tal pagamento, a preocupação não é como pagamento pela exposição à insalubridade, mas com a diminuição do risco, de forma compartilhada, conforme Marcia Ramazzini: ${ }^{30}$

\begin{abstract}
Em outros países, a relação trabalho e emprego é compartilhada e tem efeito muito mais efetivo e eficiente. Os funcionários são conscientes e têm uma corresponsabilidade. Nos Estados Unidos, o Ministério do Trabalho (OSHA) é usado como referência consultiva para pequenas e grandes empresas, a cada três anos são auditadas e, caso as informações anuais enviadas através de relatórios não retratem a realidade, ou constatadas irregularidades recebem autuações.
\end{abstract}

De qualquer sorte, no Brasil, o adicional de insalubridade se dá pelo pagamento de um percentual sobre base de cálculo. Veja-se o dispositivo na CLT: ${ }^{31}$

\begin{abstract}
Art. 192 - O exercício de trabalho em condições insalubres, acima dos limites de tolerância estabelecidos pelo Ministério do Trabalho, assegura a percepção de adicional respectivamente de $40 \%$ (quarenta por cento), $20 \%$ (vinte por cento) e $10 \%$ (dez por cento) do salário-mínimo da região, segundo se classifiquem nos graus máximo, médio e mínimo.
\end{abstract}

Nos estatutos de servidores públicos, é comum a vinculação do percentual a ser percebido ao salário mínimo ou seu valor, já que cada Município e Estado brasileiros devem ter seu estatuto próprio (no sentido de regime jurídico único). Mesmo o estatuto dos servidores federais, Lei 8112/90, hoje estabelece em seu art. 68, que: "Os servidores que trabalhem com habitualidade em locais insalubres ou em contato permanente com substâncias tóxicas, radioativas ou com risco de vida, fazem jus a um adicional sobre o vencimento do cargo efetivo", mas tal base no vencimento do cargo é fruto de recente alteração legislativa.

Portanto, a questão que se coloca, diante da norma celetista ou das normas estatutárias eventualmente, é sobre a possibilidade de determinar o pagamento de adicional de insalubridade com base no percentual sobre o salário mínimo. Isso porque o art. $7^{\circ}$, IV da Constituição de 1988 veda vinculação ao salário mínimo. Há farta jurisprudência sobre o tema, inclusive com edição de Súmula $n^{\circ} 4$ pelo STF:

\footnotetext{
Salvo nos casos previstos na Constituição, o salário mínimo não pode ser usado como indexador de base de cálculo de vantagem de servidor público ou de empregado, nem ser substituído por decisão judicial.
}

Sobre o entendimento de que não pode haver decisão judicial substituindo a base de cálculo, cite-se a Rcl 13685 AgR-segundo / DF - DISTRITO FEDERAL em que se reitera a 
proibição de decisão judicial a substituir a base de cálculo, nada referindo-se nessa decisão quanto ao Executivo.

De um lado, o entendimento do STF fez alterar a jurisprudência trabalhista. Veja-se a redação da Súmula 228 do TST:

ADICIONAL DE INSALUBRIDADE. BASE DE CALCULO. A partir de 9 de maio de 2008, data da publicação da Súmula Vinculante $n^{\circ} 4$ do Supremo Tribunal Federal, o adicional de insalubridade será calculado sobre o salário básico, salvo critério mais vantajoso fixado em instrumento coletivo.

Todavia, em decisão transitada em julgado na Reclamação 6.266/DF o STF entendeu por suspender parte dessa Súmula 228 do TST:

\begin{abstract}
Portanto, mostra-se inafastável a conclusão de que a decisão proferida pelo Plenário do TST, que editou a Resolução 148/2008 e deu nova redação à Súmula 228 daquela Corte, ao estipular o cálculo do adicional de insalubridade devido com base no salário profissional, contrariou o entendimento firmado por esta Corte a respeito da aplicação do enunciado da Súmula Vinculante 4.

Isso posto, com base na jurisprudência firmada nesta Corte (art. 161, parágrafo único, do RISTF), julgo procedente esta reclamação para cassar a Súmula 228 do TST, apenas e tão somente na parte em que estipulou o salário básico do trabalhador como base de cálculo do adicional de insalubridade devido.
\end{abstract}

Essa decisão, como outras, reitera que o Poder Judiciário não pode fixar a base de cálculo do adicional de insalubridade. ${ }^{32}$

De outro lado, em relação ao regime estatutário, no julgamento que deu base a Súmula 4 do STF ficou clara a impossibilidade de se utilizar o salário mínimo como base de cálculo para o adicional de insalubridade, relativo à legislação estatutária de São Paulo (Lei 432/85, conforme redação à época). Como já se disse, ficou decidido que o próprio STF, por interpretação, não poderia alterar e definir outra base de cálculo. De fato, a base de cálculo em salários mínimos foi alterada por lei estadual de 2012.

Em vista dos vários estatutos jurídicos de servidores públicos estaduais e municipais e considerando que muitos ainda podem referir a vinculação ao salário mínimo, coloca-se a questão antes ${ }^{33}$ e após a Súmula Vinculante: É possível, por interpretação jurídica do Poder Executivo, a alteração da base de cálculo do adicional de insalubridade sem nova lei, considerando a norma estadual/municipal inconstitucional?

O exemplo da inconstitucionalidade de base de cálculo vinculada ao salário mínimo é situação pacificada, com o que fica mais aproximada uma resposta à questão acima. Com a edição da Súmula vinculante, o Poder Executivo fica adstrito à sua interpretação por força do entendimento processual. Mas antes da edição da Súmula, já se poderia vislumbrar apoio na doutrina do controle de constitucionalidade para que o Poder Executivo pudesse declarar a base de cálculo em salário mínimo como inconstitucional, mesmo sem decisão específica sobre tal ou qual estatuto de servidores.

Portanto, parece claro que, motivadamente, o Poder Executivo pode declarar inconstitucionalidade a respeito de base de cálculo de adicional de insalubridade e inclusive determinar nova forma de cálculo, desde que de acordo com outros dispositivos constitucionais e da irredutibilidade de vencimentos. 


\section{CONCLUSÃO}

O Poder Executivo pode afastar o cumprimento de normas com base no argumento de estarem em desacordo com a Constituição, fundado no princípio da Supremacia da Constituição. E, nesse sentido, o princípio da legalidade não é óbice para que o Poder Executivo possa controlar a constitucionalidade, ao contrário, é interpretado o princípio da legalidade no sentido de que é dirigido apenas às normas que são constitucionais.

Para o Supremo Tribunal Federal é possível deixar de aplicar a norma, mesmo no âmbito do Poder Executivo, em casos concretos, em que a lei esteja em desalinho com a Constituição de 1988.

Por fim, na questão do adicional de insalubridade, devido a empregados regidos pela Consolidação das Leis do Trabalho (CLT) e a servidores públicos, também o Poder Executivo, no que tange ao estatuto dos servidores, pode deixar de aplicar norma relativa à base de cálculo do adicional de insalubridade. Isso com fundamento na inconstitucionalidade de norma que determina a utilização do salário mínimo como indexador do percentual do adicional de insalubridade. Entende-se que também pode o Executivo fixar outra base de cálculo até que nova lei a defina, pois as decisões do STF referem a impossibilidade apenas de o Judiciário fixar outra base de cálculo que não o salário mínimo.

\section{NOTAS}

1. BRASIL. Constituição (1988). Constituição da República Federativa do Brasil. Disponível em: http:// www.planalto.gov.br/ccivil_03/constituicao/constituicao.htm. Acesso em: 26 mai. 2019.

2. MEDAUAR, Odete. Direito Administrativo Moderno. 14. ed. rev. atual. e ampl. São Paulo: Revista dos Tribunais, 2010.

3. MELLO, Celso Antônio Bandeira de. Curso de Direito Administrativo. 28. ed. rev. atual e ampl. São Paulo: Malheiros. 2011.

4. KELSEN, Hans. Teoria Pura do Direito. 6. ed. São Paulo: Martins Fontes, 1998.

5. TEMER, Michel. Elementos de Direito Constitucional. São Paulo: Ed. Malheiros, 2006. p. 44-45.

6. SILVA, José Afonso. Curso de direito constitucional positivo. 42. ed. São Paulo: Malheiros, 2019, p. 45.

7. CLĖVE, Clèmerson Merlin. A fiscalização abstrata de constitucionalidade no direito brasileiro. São Paulo: Revista dos Tribunais, 2000. p. 27.

8. MORAES, Alexandre de. Direito constitucional. 35. ed. São Paulo: Atlas, 2019. p. 1120.

9. MORAES, Alexandre de. Direito constitucional. 35. ed. São Paulo: Atlas, 2019.

10. RTJ 2/386; 3/760; RDA 59/339, 76/51, 76/308, 97/116; BDM 11/600 [...].

11. RAMOS, Elival da Silva. A inconstitucionalidade das leis: vício e sanção. São Paulo: Saraiva, 1994.

12. MEIRELLES, Hely Lopes. Direito Municipal Brasileiro. 10. ed. São Paulo: Malheiros, 1998.

13. BARROSO, Luís Roberto. O controle de constitucionalidade no direito brasileiro. 2. ed. São Paulo: Saraiva, 2006. 
14. CAMPOS, Miguel. Poder Executivo. Negativa de Aplicação de Lei Supostamente Inconstitucional: Correntes Doutrinárias. Controvérsia. Revista Jurídica da Procuradoria Geral do Estado do Paraná, Curitiba, n. 2, p. 11-32, 2011.

15. ANDRADE, Flávio da Silva. Sobre a possibilidade de controle de constitucionalidade de lei pelo Poder Executivo. Revista CEJ, Brasília, Ano XV, n. 52, p. 6-11, jan./mar. 2011

16. DUARTE, Sara Meinberg Schmidt de Andrade. Possibilidade de os Estados-membros editarem, no âmbito da competência legislativa concorrente, lei que afronte normas gerais nacionais que estejam em desconformidade com a Constituição da República, ainda que a inconstitucionalidade das normas gerais não tenha sido reconhecida pelo Poder Judiciário. Minas Gerais. 2003. 36-37 f. Monografia (especialização em Poder Legislativo) - Instituto de Educação Continuada, Pontifícia Universidade Católica.

17. CAMPOS, Miguel. Poder Executivo. Negativa de Aplicação de Lei Supostamente Inconstitucional: Correntes Doutrinárias. Controvérsia. Revista Jurídica da Procuradoria Geral do Estado do Paraná, Curitiba, n. 2, p. 11-32, 2011.

18. HESSE, Konrad. A força normativa da constituição. Tradução Gilmar Ferreira Mendes. Porto Alegre: Sergio Antonio Fabris, 1991, p. 19.

19. CAMPOS, Miguel. Poder Executivo. Negativa de Aplicação de Lei Supostamente Inconstitucional: Correntes Doutrinárias. Controvérsia. Revista Jurídica da Procuradoria Geral do Estado do Paraná, Curitiba, n. 2, p. 11-32, 2011.

20. ANDRADE, Flávio da Silva. Sobre a possibilidade de controle de constitucionalidade de lei pelo poder executivo. Revista CEJ, Brasília, Ano XV, n. 52, p. 6-11, jan./mar. 2011.

21. ANDRADE, Flávio da Silva. Sobre a possibilidade de controle de constitucionalidade de lei pelo poder executivo. Revista CEJ, Brasília, Ano XV, n. 52, p. 6-11, jan./mar. 2011.

22. BRASIL. Supremo Tribunal Federal. Mandado de Segurança n. 27.744-DF. $1^{\text {a }}$ Turma. Relator Min. Luiz Fux. Pesquisa de Jurisprudência, Acórdãos. Disponível em: http://www.stf.jus.br/portal/jurisprudencia/pesquisarJurisprudencia.asp. Acesso em: 04 jun. 2019.

23. BRASIL. Supremo Tribunal Federal. Mandado de Segurança n. 27.744-DF. $1^{\text {a }}$ Turma. Relator Min. Luiz Fux. Pesquisa de Jurisprudência, Acórdãos. Disponível em: http://www.stf.jus.br/portal/jurisprudencia/pesquisarJurisprudencia.asp. Acesso em: 04 de jun. 2019.

24. BRASIL. Supremo Tribunal Federal. Mandado de Segurança n. 27.744-DF. $1^{\text {a }}$ Turma. Relator Min. Luiz Fux. Pesquisa de Jurisprudência, Acórdãos. Disponível em: http://www.stf.jus.br/portal/jurisprudencia/pesquisarJurisprudencia.asp. Acesso em: 04 de jun. 2019.

25. DELGADO, Maurício Godinho. Curso de Direito do Trabalho. São Paulo: LTr, 2012, p. 759.

26. LEITE, Carlos Henrique Bezerra. Curso de Direito do Trabalho. São Paulo: Saraiva, 2014, p. 346.

27. MOURA, Marcelo. Curso de Direito do Trabalho. São Paulo: Saraiva, 2014, p. 209.

28. RUSSOMANO, Mozart Victor. Curso de Direito do Trabalho. Curitiba: Juruá, 2005, p. 396-398.

29. CASSAR, Vólia Bomfim. Direito do Trabalho: de acordo com a reforma trabalhista Lei 13.467/2017. 15. ed. Rio de Janeiro: Forense, 2018, p. 820.

30. RAMAZZINI, Marcia. Brasil, O País Dos Adicionais. Disponível em: https://www.rhportal.com.br/ artigos-rh/brasil-o-pas-dos-adicionais/. Acesso em: 01 jul. 2019.

31. Esse dispositivo, como se verá adiante, é considerado inconstitucional por não ter sido recepcionado pela ordem constitucional conforme SILVA, Homero Batista Mateus da. Curso de Direito do Trabalho Aplicado. 3. ed. Vol.3. São Paulo: RT, 2017, p.152-3. 
KLEIN, Mateus de Farias; OLIVEIRA, Cristiane Catarina Fagundes de - Controle de constitucionalidade pelo Poder Executivo e o adicional de insalubridade a funcionários e servidores públicos

32. GARCIA, Gustavo Filipe Barbosa. Meio Ambiente do Trabalho. 4ª ed. São Paulo: Método, 2014, p. 196.

33. GARCIA, Gustavo Filipe Barbosa. Meio Ambiente do Trabalho. 4. ed. São Paulo: Método, 2014, p. 210: "Portanto, mesmo antes da aprovação da Súmula Vinculante 4 do STF, já era lícito dizer que, para os servidores públicos, (vinculados aos entes de direito público), regidos pela legislação trabalhista, não se pode utilizar o salário mínimo como indexador de base de cálculo de vantagem devida como é o caso do adicional de insalubridade; aos estatutários, da mesma forma, não se pode vincular o adicional de insalubridade ao salário mínimo."

\section{REFERÊNCIAS}

ANDRADE, Flávio da Silva. Sobre a possibilidade de controle de constitucionalidade de lei pelo Poder Executivo. Revista CEJ, Brasília, Ano XV, n. 52, p. 6-11, jan./mar. 2011.

BARROSO, Luís Roberto. O controle de constitucionalidade no direito brasileiro. 2. ed. São Paulo: Saraiva, 2006.

BRASIL. Constituição (1988). Constituição da República Federativa do Brasil. Disponível em: http:// www.planalto.gov.br/ccivil_03/constituicao/constituicao.htm. Acesso em: 26 de mai. de 2019.

BRASIL. Supremo Tribunal Federal. Mandado de Segurança n. ${ }^{2}$ 27.744-DF. Impetrante: Ministério Público do Estado de Santa Catarina. Impetrado: Conselho Nacional do Ministério Público (PROCEDIMENTO

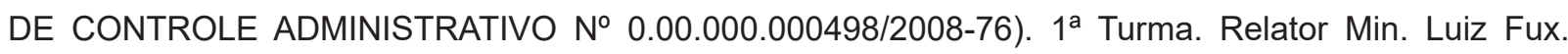
Brasília, 14.04.2015. Pesquisa de Jurisprudência, Acórdãos. Disponível em: http://www.stf.jus.br/portal/ jurisprudencia/pesquisarJurisprudencia.asp. Acesso em: 04 de jun. 2019.

CAMPOS, Miguel. Poder Executivo. Negativa de Aplicação de Lei Supostamente Inconstitucional: Correntes Doutrinárias. Controvérsia. Revista Jurídica da Procuradoria Geral do Estado do Paraná, Curitiba, n. 2, p. 11-32, 2011.

CASSAR, Vólia Bomfim. Direito do Trabalho: de acordo com a reforma trabalhista Lei 13.467/2017. 15. ed. Rio de Janeiro: Forense, 2018.

CLÈVE, Clèmerson Merlin. A fiscalização abstrata de constitucionalidade no direito brasileiro. São Paulo: Editora Revista dos Tribunais, 2000.

DELGADO, Maurício Godinho. Curso de Direito do Trabalho. São Paulo: LTr, 2012.

DUARTE, Sara Meinberg Schmidt de Andrade. Possibilidade de os Estados-membros editarem, no âmbito da competência legislativa concorrente, lei que afronte normas gerais nacionais que estejam em desconformidade com a Constituição da República, ainda que a inconstitucionalidade das normas gerais não tenha sido reconhecida pelo Poder Judiciário. Minas Gerais. 2003. 3637 f. Monografia (especialização em Poder Legislativo) - Instituto de Educação Continuada, Pontifícia Universidade Católica.

FRANCO FILHO, Alberto de Magalhães. O controle de constitucionalidade de normas municipais. In: Âmbito Jurídico, Rio Grande, XII, n. 70, nov 2009. Disponível em: http://www.ambitojuridico.com.br/site/ index.php?n_link=revista_artigos_leitura\&artigo_id=6648. Acesso em: mai. 2017.

GARCIA, Gustavo Filipe Barbosa. Meio Ambiente do Trabalho. 4. ed. São Paulo: Método, 2014. 
LEITE, Carlos Henrique Bezerra. Curso de Direito do Trabalho. São Paulo: Saraiva, 2014.

MEDAUAR, Odete. Direito Administrativo Moderno. 14 ed. rev. e atual. São Paulo: editora Revista dos Tribunais, 2010.

MEIRELLES, Hely Lopes. Direito Municipal Brasileiro. 10. ed. São Paulo: Malheiros, 1998.

MELLO, Celso Antônio Bandeira de. Curso de Direito Administrativo. 28. ed. rev. e atual. Até a emenda constitucional 67. São Paulo: Malheiros editores. 2011.

MORAES, Alexandre de. Direito constitucional. 35. ed. São Paulo: Atlas, 2019.

MOURA, Marcelo. Curso de Direito do Trabalho. São Paulo: Saraiva, 2014.

RAMOS, Elival da Silva. A inconstitucionalidade das leis: vício e sanção. São Paulo: Saraiva, 1994.

REVERBEL, Carlos Eduardo Dieder. Direito Constitucional. 2017. Notas de Aula.

RUSSOMANO, Mozart Victor. Curso de Direito do Trabalho. Curitiba: Juruá, 2005.

SILVA, Homero Batista Mateus da. Curso de Direito do Trabalho Aplicado. 3. ed. v. 3. São Paulo: RT, 2017.

SILVA, José Afonso. Curso de direito constitucional positivo. 42. ed. São Paulo: Ed. Malheiros, 2019.

TEMER, Michel. Elementos de Direito Constitucional. São Paulo: Ed. Malheiros, 2006.

Recebido em: 01/07/2019

Aceito em: 31/07/2019 